\title{
Karakteristik Kategori Kecepatan Angin di Kota Majene dengan Pendekatan Rantai Markov
}

\author{
Muhammad Abdy*1, Wahidah Sanusi ${ }^{2}$ \\ 1,2 Universitas Negeri Makassar \\ e-mail: *11 muh.abdy@unm.ac.id, ${ }^{2}$ wahidah.sanusi@unm.ac.id
}

\begin{abstract}
Abstrak
Kajian ini mengaplikasikan model rantai Markov pada data kecepatan angin harian yang dikumpulan oleh stasiun Badan Meteorologi dan Geofisika kabupaten Majene dari tahun 1982 sampai dengan tahun 2005. Kajian ini bertujuan untuk menganalisis karakteristik kategori kecepatan angin dengan menghitung peluang steady state, nilai harapan masa tinggal dan nilai harapan masa perulangan pertama. Pengkategorian kecepatan angin dibuat berdasarkan skala Beaufort, yaitu dari skala 0 sampai dengan skala 9. Nilai peluang steady state menunjukkan bahwa kategori angin dengan hembusan lembut mempunyai peluang kemunculan yang terbesar, yaitu sekitar 43,33\%, dan kategori angin tenang mempunyai peluang kemunculan yang paling kecil, yaitu sekitar 0,02\%. Sementara dari nilai harapan masa tinggal dan nilai harapan masa perulangan pertama menunjukkan bahwa kategori kecepatan angin dengan hembusan lembut mempunyai durasi kejadian terlama, yaitu sekitar 2 hari, dan mempunyai durasi paling singkat untuk terjadi kembali setelah terjadi pada kejadian sebelumnya, yaitu sekitar 2,3 hari.
\end{abstract}

Kata Kunci: Rantai Markov, Kecepatan Angin, Skala Beaufort

\section{PENDAHULUAN}

Angin didefinisikan sebagai pergerakan udara ke segala arah. Kecepatan angin bervariasi dari tenang hingga kecepatan badai yang sangat tinggi. Angin terbentuk ketika udara bergerak dari daerah bertekanan tinggi ke daerah di mana tekanan udara rendah. Perubahan suhu musiman dan rotasi bumi juga mempengaruhi kecepatan dan arah angin (Alan, 2017).

Kecepatan angin merupakan hal penting dalam prakiraan cuaca dan mempengaruhi fungsi utama lainnya seperti penyerbukan pada tumbuhan, laju metabolisme spesies tanaman, dan faktor antropogenik lainnya (David, 2020). Kecepatan angin juga dapat digunakan untuk menentukan awal musim baru atau terjadinya cuaca besar (Alan, 2017). Kecepatan angin biasanya diukur dengan anemometer, yang merupakan instrumen stasiun cuaca umum.

Kecepatan angin dipengaruhi oleh berbagai faktor mikro dan makro, seperti gradien tekanan. Gradien tekanan didefinisikan sebagai perbedaan tekanan udara antara dua titik atmosfer. Pada dasarnya, semakin besar perbedaan dalam tekanan, semakin cepat angin akan mengalir dari atmosfer bertekanan tinggi ke rendah untuk menyeimbangkan fluktuasi. Faktor-faktor seperti angin topan, tornado, dan monsun dapat mempengaruhi kecepatan angin secara regional dan lokal.

Beberapa artikel tentang pemodelan kecepatan angin telah banyak dilakukan oleh para ahli. Novitasari, Febrianti dan Setiawan (2017) menggunakan algoritma Forward-Backward dalam Hidden Markov Model untuk menganalisis kecepatan angin. So-Kummeth dan Philip (2019) memodelkan kecepatan angin dengan menggunakan proses ARIMA tersarang. Benth (2010) menganalisis dan memodelkan kecepatan angin di New York dengan model ARMA. Lisa (2013) menggabungkan beberapa metode statistika untuk memodelkan dan meramalkan kecepatan angin. Karatepe dan Kenneth (2013) mengestimasi kecepatan angin dengan memasukkan data musiman menggunakan rantai markov.

Pengklassifikasi kecepatan angin biasa menggunakan skala Beaufort (Hasan, Affaf dan Salleh, 2017). Skala ini mengukur kecepatan angin dengan menggambarkan pengaruhnya pada kecepatan kapal dan gelombang air laut. Skala Beaufort menggunakan angka dan symbol (Bayong, 2017). Kondisi angin di kota Majene sangat dipengaruhi oleh angin musim, hal ini disebabkan oleh wilayahnya yang berbatasan langsung

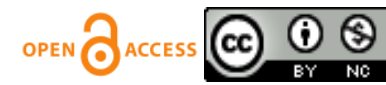


dengan laut lepas, yaitu Selat Makassar dan Teluk Mandar (BPS, 2018). Kondisi angin tersebut sangat mempengaruhi frekuensi trip penagkapan ikan oleh para nelayan. Hal ini disebabkan oleh tinggi gelombang yang dipengaruhi oleh kecepatan angin.

Tujuan dari penelitian ini adalah menganalisis karakteristik kategori kecepatan angin di kota Majene dengan menggunakan rantai Markov orde pertama. Karakteristik dari kategori kecepatan angin difokuskan pada (a) peluang steady state kategori kecepatan angin, (b) Nilai harapan durasi terjadinya suatu kategori kecepatan angin, dan (c) nilai harapan durasi terjadinya kembali suatu kategori kecepatan angin setelah kejadian sebelumnya.

\section{METODE PENELITIAN}

\subsection{Rantai Markov}

Suatu proses stokastik $X=\left\{X_{n}, n \in N\right\}$ pada suatu ruang state $S$ merupakan suatu rantai Markov waktu diskrit jika:

$$
\begin{aligned}
& \quad \forall n \geq 0, X_{n} \in S, \\
& \text { - } \quad \forall n \geq 1 \text { dan } \forall i_{0}, i_{1}, \ldots, i_{n-1} \in S, \text { maka } \\
& \operatorname{Pr}\left\{X_{n}=i_{n} \mid X_{n-1}=i_{n-1}, X_{n-2}=i_{n-2}, \ldots, X_{0}=i_{0}\right\}=\operatorname{Pr}\left\{X_{n}=i_{n} \mid X_{n-1}=i_{n-1}\right\}
\end{aligned}
$$

Suatu rantai Markov waktu-diskrit $X=\left\{X_{n}, n \in N\right\}$ pada suatu state $S$ disebut homogen jika $\forall n, k \in N$ dan $\forall i, j \in S$, maka $\operatorname{Pr}\left\{X_{n+k}=j \mid X_{k}=i\right\}=\operatorname{Pr}\left\{X_{n}=j \mid X_{0}=i\right\}$

\subsubsection{Peluang Transisi}

Misalkan $\operatorname{Pr}\left\{X_{n}=j \mid X_{n-1}=i\right\}=t_{i j}$ disebut peluang transisi dari state $i$ pada waktu $n-1$ ke state $j$ pada waktu $n$, maka $t_{i j}$ dapat dinyatakan dalam bentuk matriks peluang transisi, sebagai berikut:

$T=\left(t_{i j}\right)=\left[\begin{array}{ccc}t_{11} & \cdots & t_{1 s} \\ \vdots & \ddots & \vdots \\ t_{s 1} & \cdots & t_{s s}\end{array}\right], i, j=1,2, \ldots, s$

dimana $0 \leq t_{i j} \leq 1$ dan $\sum_{j \in S} t_{i j}=1, i=1,2, \ldots, s ;$ dan $s$ adalah banyaknya state.

Nilai-nilai $t_{i j}$ dapat diestimasi dari data yang diberikan. Beberapa metode estimasi $t_{i j}$ telah banyak digunakan, diantaranya metode kemungkinan maksimum dan metode Bayes (Wahidah, 2015). Untuk kajian ini digunakan metode kemungkinan maksimum, yaitu

$$
\widehat{t}_{i j}=\frac{f_{i j}}{F_{i .}}
$$

dimana $f_{i j}$ adalah banyaknya transisi, dan $F_{i .}=\sum_{j=1}^{s} f_{i j} ; i, j=1,2, \ldots, s$

Peluang $X_{n+1}$ ada pada state $j$ jika diketahui $X_{n}$ ada pada state $i$, disebut peluang transisi satu-langkah, yang dinyatakan dengan $t_{i j}^{(n, n+1)}$, yaitu $t_{i j}^{(n, n+1)}=\operatorname{Pr}\left\{X_{n+1}=j \mid X_{n}=i\right\}$, sehingga peluang transisi $k$-langkah adalah $t_{i j}^{(n, n+k)}=\operatorname{Pr}\left\{X_{n+k}=j \mid X_{n}=i\right\}$. Dengan menggunakan Teorema Chapman -Kolmogorov, maka diperoleh matriks peluang transisi $k$-langkah, sebagai:

$$
T^{(n, n+k)}=\left[\begin{array}{ccc}
t_{11} & \cdots & t_{1 s} \\
\vdots & \ddots & \vdots \\
t_{s 1} & \cdots & t_{s s}
\end{array}\right]^{k}
$$


Jika rantai Markov adalah ergodik, maka untuk $k \rightarrow \infty ; t_{i j}^{(n, n+1)}$ akan konvergen ke suatu nilai $\prod_{j}$ yang hanya tergantung pada nilai $j$ (Ross, 2007). Nilai-nilai dari $\prod_{j}$ merupakan nilai dari keadaan steady state system.

\subsubsection{Nilai Harapan Masa Tinggal (NHMT)}

Misalkan $t_{j j}$ adalah peluang transisi suatu rantai Markov dari state $j$ ke state $j$, dan $R_{j}$ adalah masa tinggal state $j$, maka $\operatorname{Pr}\left(R_{j}=k\right)=\operatorname{Pr}\left(X_{n+1}=j \mid X_{n}=j\right\}$

$$
=\ldots=\operatorname{Pr}\left(X_{n+k} \neq j \mid X_{n+k-1}=j\right)=t_{j j}{ }^{(k-1)} 1-t_{j j}
$$

$R_{j}$ berdistribusi geometrik dengan parameter $1-t_{j j}$, sehingga nilai harapan masa tinggal state $j$ adalah

$E\left(R_{j} \mid X_{n}\right)=\frac{1}{1-t_{j j}}$ (Wahidah, 2015)

\subsubsection{Nilai Harapan Masa Perulangan Pertama (NHMPP)}

Misalkan variabel acak $\tau(j)$ adalah banyaknya transisi yang diperlukan untuk mencapai state $j$ didefinisikan sebagai $\tau(j)=\inf \left\{n \geq 1 \mid X_{n}=j\right\}$, maka waktu $\tau(j)$ yang disimbolkan dengan $P_{i j}$ disebut masa perulangan pertama dari state $i$ ke state $j$. Nilai harapan dari $P_{i j}$ didefinisikan sebagai

$M_{i j}=E\left[P_{i j}=n\right]=M_{i j}=1+\sum_{\substack{k=1 \\ k \neq j}}^{s} t_{i k} M_{k j}, \forall i, j=1,2, \ldots, s$

atau dalam bentuk matriks: $M=E+T\left(M-M_{d}\right)$,

dimana $M=\left(M_{i j}\right), E=$ matriks identitas, $T=\left(t_{i j}\right)$, dan $M_{d}=M_{j j}$ (Wahidah, 2015)

\subsubsection{Skala Beaufort}

Skala Beaufort digunakan untuk mengkategorikan kecepatan angin yang diperoleh. Skala ini mengukur kecepatan angin dengan mendeskripsikan pengaruhnya. Skala ini diperkenalkan pertama kali oleh Admiral F. Beaufort. Secara detail, skala Beaufort (Bayong, 2017) diberikan dalam Tabel 1.

Tabel 1 Skala Beaufort

\begin{tabular}{|c|l|c|}
\hline Skala Beaufort & Kategori angina & Kecepatan angin $(\mathrm{m} /$ detik) \\
\hline 0 & Tenang & $0-0,2$ \\
1 & Udara ringan & $0,3-1,5$ \\
2 & Hembusan lemah & $1,6-3,3$ \\
3 & Hembusan lembut & $3,4-5,4$ \\
4 & Hembusan sedang & $5,5-7,9$ \\
5 & Hembusan segar & $8,0-10,7$ \\
6 & Hembusan kuat & $10,8-13,8$ \\
7 & Angin ribut lemah & $13,9-17,1$ \\
8 & Angin ribut & $17,2-20,7$ \\
9 & Angin ribut kuat & $20,8-24,4$ \\
10 & Badai & $24,5-28,4$ \\
11 & Badai amuk & $28,5-32,6$ \\
12 & Siklon & $\geq 32,7$ \\
\hline
\end{tabular}

Pada kajian ini, skala Beaufort yang digunakan adalah skala 0 sampai dengan skala 9. Skala yang lebih dari 9 tidak digunakan karena kecepatan angin yang terbesar dari data adalah $23 \mathrm{~m} /$ detik.

\subsubsection{Lokasi dan Sumber Data}

Lokasi penelitian ini adalah kota Majene, yang terletak diantara $2^{0} 38^{\prime} 45^{\prime \prime}$ dan 3038'15" Lintang Selatan dan antara $118^{\circ} 45^{\prime} 00^{\prime}$ dan $11^{\circ} 05^{\prime} 00^{\prime \prime}$ Bujur Timur, dengan luas wilayah 947,84 km². Kondisi iklim 
wilayah kota Majene dan sekitarnya secara umum ditandai dengan hari hujan dan curah hujan yang relatif tinggi dan sangat dipengaruhi oleh angin musim, hal ini dikarenakan wilayahnya berbatasan dengan laut lepas. Data kecepatan angin harian yang digunakan dalam kajian ini diperoleh dari stasiun Badan Meteorologi dan Geofisika kelas II Majene, untuk periode tahun 1982 sampai dengan 2005.

\section{HASIL DAN PEMBAHASAN}

Skala Beaufort yang digunakan dalam mengkategorikan data kecepatan angin dalam kajian ini adalah dari skala 0 sampai dengan skala 9. Skala 10 sampai dengan skala 12 tidak digunakan karena kecepatan angin maksimum dari data adalah $23 \mathrm{~m} /$ detik. Kategori kecepatan angin dijadikan sebagai state, sehingga terdapat 9 state pada rantai Markov. Kecepatan angin rata-rata pada setiap bulannya (Januari sampai dengan Desember) terdapat dalam Tabel 2. Rata-rata kecepatan angin pada setiap bulannya berada pada kategori 3 dan 4 (hembusan lembut dan hembusan sedang). Rata-rata kecepatan angin terbesar terjadi pada bulan Agustus, yaitu sebesar $6,70 \mathrm{~m} /$ detik, dan rata-rata kecepatan angin yang paling rendah terjadi pada bulan Mei, yaitu 4,72 $\mathrm{m} /$ detik.

Nilai peluang steady state kategori kecepatan angin yang menyatakan peluang terjadinya kesembilan kategori kecepatan angin terdapat dalam Tabel 3. Kategori 3 (hembusan lembut) mempunyai peluang terbesar untuk terjadi yaitu sekitar 43,33\%, sedangkan kategori 0 dan 1 (tenang dan udara ringan) mempunyai peluang yang terkecil untuk terjadi, yaitu hanya sekitar $0,02 \%$. Sementara kategori angin ribut kuat mempunyai peluang untuk terjadi sekitar $0,08 \%$.

Nilai NHMT yang merupakan durasi kategori kecepatan angin terjadi ada juga dalam Tabel 3. Kecepatan angin kategori 3 mempunyai nilai NHMT terbesar, yaitu 2,02, yang berarti bahwa durasi terjadinya kategori hembusan lembut adalah sekitar 2,02 hari, sementara kategori yang lain mempunyai durasi sekitar satu hari saja.

Nilai NHMPP yang merupakan durasi suatu kategori kecepatan angin akan terjadi kembali setelah sebelumnya pernah terjadi terdapat dalam Tabel 3. Kategori hembusan lembut mempunyai nilai NHMPP yang terkecil, yaitu 2,31 hari, yang berarti bahwa kategori hembusan angin lembut akan terjadi kembali setelah sekitar 2,31 hari terjadi sebelumnya. Kategori dengan nilai NHMPP terbesar adalah kategori angin tenang dan udara ringan, yaitu sebesar 5000 hari, yang berarti bahwa kedua kategori tersebut akan berulang terjadi setelah sekitar 5000 hari atau sekitar 13,9 tahun terjadi sebelumnya. Sementara angin ribut kuat akan kembali terjadi setelah terjadi sekitar 1250 hari atau sekitar 3,5 tahun dari kejadian sebelumnya.

Tabel 2 Rerata kecepatan angin setiap bulan

\begin{tabular}{|c|c|c|}
\hline Bulan & Rerata kecepatan angin (m/detik) & Kategori \\
\hline Januari & 5.98 & 4 \\
Februari & 6.51 & 4 \\
Maret & 5.80 & 4 \\
April & 5.30 & 3 \\
Mei & 4.72 & 3 \\
Juni & 5.37 & 3 \\
Juli & 6.21 & 4 \\
Agustus & 6.70 & 4 \\
September & 5.95 & 4 \\
Oktober & 5.11 & 3 \\
Nopember & 5.61 & 3 \\
Desember & 6.43 & 4 \\
\hline
\end{tabular}


https://jurnal.unsulbar.ac.id/index.php/saintifik

Tabel 3 Peluang steady state, nilai NHMT dan nilai NHMPP pada tiap kategori

\begin{tabular}{|l|c|c|c|}
\hline \multicolumn{1}{|c|}{ Kategori angin } & $\begin{array}{c}\text { Peluang steady } \\
\text { state }\end{array}$ & NHMT (harian) & NHMPP (harian) \\
\hline Tenang & 0,0002 & 1,00 & 5.000 \\
Udara ringan & 0,0002 & 1,00 & 5.000 \\
Hembusan Lemah & 0,1083 & 1,36 & 9,23 \\
Hembusan Lembut & 0,4333 & 2,02 & 2,31 \\
Hembusan Sedang & 0,2276 & 1,42 & 4,39 \\
Hembusan Segar & 0,2023 & 1,59 & 4,94 \\
Hembusan kuat & 0,0179 & 1,10 & 55,87 \\
Angin ribut lemah & 0.0067 & 1,10 & 149,25 \\
Angin ribut & 0.0025 & 1.05 & 400 \\
Angin ribut kuat & 0.0008 & 1,00 & 1.250 \\
\hline
\end{tabular}

\section{KESIMPULAN}

Dalam kajian ini, model rantai Markov waktu-diskrit digunakan untuk mengidentifikasi karakteristik stokastik kecepatan angin di kota Majene dengan menganalisis peluang dari 9 kategori kecepatan angin berdasarkan skala Beaufort. Rata-rata kecepatan angin terbesar (kategori hembusan lembut) terjadi pada bulan Agustus setiap tahun. Sementara kecepatan angin paling lemah (kategori hembusan lemah) terjadi pada bulan Mei setiap tahunnya.

Kategori hembusan lembut merupakan kategori kecepatan angin yang paling besar peluang kemunculannya, sementara kategori tenang dan udara ringan yang paling kecil peluang kemunculannya. Nilai NHMT dan NHMPP juga memperlihatkan bahwa kategori hembusan lembut mempunyai durasi terpanjang kejadiannya dan mempunyai durasi terpendek untuk terjadi kembali setelah kejadian sebelumnya. Sementara kategori angin tenang, udara ringan dan angin ribut kuat mempunyai durasi terpendek kejadiannya, dan mempunyai durasi terlama untuk terjadi setelah kejadian sebelumnya.

\section{DAFTAR PUSTAKA}

Alan, F. A, 2017, Discovering Physical Geography, 4th Edition, Wiley, ISBN: 978-1-119-32124-8

Badan Pusat Statistik, 2018, Majene Dalam Angka 2018, Majene: BPS Kabupaten Majene

Bayong Tjasyono, 2017, Sistim Angin, Disampaikan pada Workshop Turbin Angin Kecepatan Rendah dan Peta Resolusi Angin Kecepatan Tinggi, 21 - 22 Agustus 2017, Bandung.

Benth, J. S and Benth, F. E, 2010, Analysis and Modelling of Wind Speed in New York, Journal of Applied Statistics Vol 37, No 6:.893 -909.

David, B "The Four Forces that Influence Wind Speed \& Wind Direction", https://sciencing.com/list-7651707four-wind-speed-wind-direction.html.

Hasan, H, Affaf, M, Salleh, H, 2017, Application of Markov chain to Wind Speed in Northern Peninsular Malaysia, Journal of Applied and Physical Sciences, 3(2): 52-57.

Karatepe, S and Kenneth, W. C, 2013, Wind Speed Estimation: Incorporating Seasonal Data Using Markov Chain Models, Renewable Energy, Article ID 657437

Lisa Bramer, 2013, Methods for modeling and forecasting wind characteristics, Dissertation, Iowa State University.

Novitasari, D. C. R., Febrianti,F, Setiawan, F, 2018, Analisis Kecepatan Angin pada Pasang Surut Air Laut dengan menggunakan Algoritma Forward-Backward dalam Hidden Markov Model di Wilayah Pelabuhan Tanjung Perak Surabaya, Jurnal Sains Matematika dan Statistika, Vol. 4, No. 1: 26 - 35.

Ross, S. M., 2007, Introduction to Probability Models, 9th ed, Academic Press, California.

So-Kumneth Sim, Philipp Mass and Pedro G. Lind, 2019, Wind Speed Modeling by Nested ARIMA Processes 
https://jurnal.unsulbar.ac.id/index.php/saintifik

W. Sanusi, A. A. Jemain, W. Z. W. Zin, M. Zahari, 2015, The Drought Characteristics using the First-Order Homogeneous Markov Chain of Monthly Rainfall Data in Peninsular Malaysia, Water Resource Management, Vol. 29: 1523 - 1539. 